\title{
The Comparison of Interleukin-17 and Interleukin-10 with Systemic Lupus Erythematosus Disease Activity
}

\author{
Dwitya Elvira ${ }^{1}$, Iris Rengganis ${ }^{1 *}$, Rudy Hidayat ${ }^{2}$, Hamzah Shatri $^{3}$ \\ ${ }^{1}$ Division of Allergy and Clinical Immunology, Department of Internal Medicine, Faculty of Medicine University of Indonesia- \\ Cipto Mangunkusumo Hospital, Jakarta, Indonesia; ${ }^{2}$ Division of Rheumatology, Department of Internal Medicine, Faculty of \\ Medicine University of Indonesia-Cipto Mangunkusumo Hospital, Jakarta, Indonesia; ${ }^{3}$ Division of Psychosomatic and Palliative \\ Medicine, Department of Internal Medicine, Faculty of Medicine University of Indonesia-Cipto Mangunkusumo Hospital, \\ Jakarta, Indonesia
}

Edited by: Slavica Hristomanova-Mitkovska Citation: Elvira D, Rengganis I, Hidayat R, Shatri H. The Comparison of Interleukin-17 and Interleukin-10 with Systemic Lupus Erythematosus Disease Activity. Open Access Maced J Med Sci. 2020Aug 25; 8(B):793-797. https://
doi.org/10.3889/oamjms.2020.4782 Keywords: Interleukin-17; Interleukin-10; Systemic lupu erythematosus; Disease activity Correspondence: Iris Rengganis, Division of Allergy an Faculty of Megy, Department of Internal Medicine, Mangunkusumo Hospital, Jakarta, Indonesia. Received: 13-Apr-2020 Revised: $07-$ May-2020 Accepted: 22-Jul-2020
Copyright: $\odot 2020$ Dwitya Elvira, Iris Rengganis, Rudy
Hidayat, Hamzah Shatri Hidayat, Hamzah Shatr Funding: This research was financially support by Hibah Publikasi Terindeks Internasional (PUTI) Saintekes, University of Indonesia in 2020 (Contract number: NKB Competing Interests: The authors have declared that no competing interests exis Open Access: This is an open-access article distribute NonCommercial 4.0 International License (CC BY-NC 4.0)

\begin{abstract}
AIM: This study was conducted to compare means of interleukin-17 (IL-17) (Th17 cytokines) and interleukin-10 (IL-10) (T-regulatory cytokines) as pro-inflammatory and anti-inflammatory cytokine with disease activity of systemic lupus erythematosus (SLE) and to investigate correlation between IL-17 cytokine serums with IL-10 in SLE patients.

METHODS: This study recruited total of 68 SLE patients which included 34 active and 34 inactive patients based on MEX-SLEDAI as disease activity tool measurement and subjects were selected using consecutive sampling method. Blood samples were taken from subjects and IL-17 and IL-10 were measured using ELISA method. Data were analyzed with SPSS 26 software.

RESULTS: Mean IL-17 was $19.67 \pm 1.299 \mathrm{pg} / \mathrm{ml}$ in active SLE group and $19.78 \pm 1.187 \mathrm{pg} / \mathrm{ml}$ in inactive group Median of IL-10 in active group was $3.63 \mathrm{pg} / \mathrm{ml}$ and in inactive group was $2.52 \mathrm{pg} / \mathrm{ml}$, respectively. No significant mean differences were found of IL-17 and IL-10 between active and inactive SLE patients $(p>0.005)$. We found significant positive correlation between IL-17 and IL-10 $(p<0.005 ; r=0.529)$

CONCLUSION: There were no significant mean differences of IL-17 and IL-10 between active and inactive SLE patients. However, we found elevated result of IL-10 in active SLE than inactive. There was positive correlation

between IL-17 and IL-10.
\end{abstract}

\section{Introduction}

The occurrence of this disease is a result of interactions between genetic, environmental, and hormonal, causing immunological disorders. T lymphocyte cells $(\mathrm{CD} 4+)$ play an important role in the occurrence of autoimmune diseases. During $T$ cell receptor activation, naive CD4 cells can differentiate into T-helper (Th)1, Th2, Th17, and T-regulator (T-reg) cells based on the production patterns and cytokine function of each T-helper cell. In SLE, this imbalance of T-helper cell cytokines is also thought to contribute to the pathogenesis of SLE [3], [4], [5].

Th17 cells produce cytokines interleukin-17 (IL-17) which acts as protection in host cells, but excessive activity can lead to autoimmune and inflammatory conditions. Recent studies also showed that homeostatic disorders that occur in autoimmune are also caused by disruption of the regulator's function, which are T-reg cells that produce cytokines interleukin-10 (IL-10). The Th17/T-reg subset is slowly replacing the old paradigm of the relationship between B cells and the Th1/Th2 subset in autoimmunity. The balance between the activity of immune regulation and inflammation of the Th17/T-reg cell subset is absolutely necessary in maintaining optimal immunity so that interference with this subset will lead to autoimmune diseases, especially SLE [6], [7], [8].

Role of the Th17 and T-regulator axis of SLE disease activity still shows controversial results. Research on IL-17 as a cytokine produced by a subset of Th17 and IL-10 as a T-reg cytokine in SLE disease activity still shows different results [9], [10].

This study was conducted to compare means of IL-17 (Th17 cytokines) and IL-10 (T-regulatory cytokines) as pro-inflammatory and anti-inflammatory cytokine with disease activity of SLE and to investigate correlation between IL-17 cytokine serums with IL-10 in SLE patients. 


\section{Methods}

This study recruited total of 68 SLE patients which included 34 active and 34 inactive patients based on MEX-SLEDAI as disease activity tool measurement and subjects were selected using consecutive sampling method. Patients with infection, severe systemic events, and other autoimmune diseases are excluded from the study. Research sites are in outpatient Department of Allergy and Immunology - Internal Medicine in Cipto Mangunkusumo General Hospital in Jakarta. All patients have signed the informed consent. This research has received an ethical approval from the Ethics Committee of Medical Faculty of University of Indonesia.

Blood samples were taken from subjects and IL-17 and IL-10 were measured using ELISA method. All data are collected and tabulated then statistical analysis is computerized using the SPSS version 26 . A value of $p<0.05$ was considered as statistically significant.

\section{Results}

In this study, from 68 total samples, $100 \%$ female samples were obtained with a median age of 31 years with a minimum age of 18 years and a maximum age of 65 years. Age group 21-40 years is the most commonly found in this study, which is $81.8 \%$ and the least is the age group 20 years as much as $11.8 \%$. Duration of SLE diagnosis in this study was obtained at most for $>1$ year by $82.4 \%$. Disease activity based on

Table 1: Baseline characteristics

\begin{tabular}{|c|c|}
\hline Characteristics & $\mathrm{n}=68$ \\
\hline \multicolumn{2}{|l|}{ Sex, n (\%) } \\
\hline Male & $0(0.0)$ \\
\hline Female & $68(100.0)$ \\
\hline Age (year old), median (min-max) & $31(18-65)$ \\
\hline \multicolumn{2}{|l|}{ Age group, $\mathrm{n}(\%)$} \\
\hline$\leq 20$ year old & $8(11.8)$ \\
\hline $21-40$ year old & $32(81.8)$ \\
\hline$>40$ year old & $18(26.5)$ \\
\hline \multicolumn{2}{|l|}{ SLE duration, $\mathrm{n}(\%)$} \\
\hline$\leq 1$ year & $12(17.6)$ \\
\hline$>1$ year & $56(82.4)$ \\
\hline \multicolumn{2}{|l|}{ Immunosuppressant, $\mathrm{n}(\%)$} \\
\hline Without & $29(85.3)$ \\
\hline Single drug & $23(67.6)$ \\
\hline Two combinations & $17(50)$ \\
\hline Three combinations & $1(2.9)$ \\
\hline \multicolumn{2}{|l|}{ Steroid, $\mathrm{n}(\%)$} \\
\hline Without & $7(10.3)$ \\
\hline Dose $\leq 4 \mathrm{mg} / \mathrm{hari}$ & $37(54.4)$ \\
\hline Dose $>4 \mathrm{mg}$ & $24(35.3)$ \\
\hline MEX SLEDAI, median (min-max) & $1(0-17)$ \\
\hline \multicolumn{2}{|l|}{ SLE } \\
\hline Active & $34(50.0)$ \\
\hline Inactive & $34(50.0)$ \\
\hline IL-17 (pg/ml), Mean (SD) & $19.73(1.24)$ \\
\hline IL-10 (pg/ml), median (min-max) & $2.96(0-11)$ \\
\hline
\end{tabular}

the MEX SLEDAI score obtained a median of 1 , with minimum score of 0 with a maximum of 17 . A total of 34 SLE patients (50\%) were active LES and $50 \%$ patients were inactive LES. In this study, $85.3 \%$ of subjects did not use immunosuppressant, followed by $67.6 \%$ with single immunosuppressant, $50 \%$ combination of two immunosuppressant, and $2.9 \%$ combination of three immunosuppressant. The highest steroid dose equivalent to $4 \mathrm{mg} /$ day was $54.4 \%$ and $10.3 \%$ were not on steroid therapy. The average IL17 level was 19.73 (1.24) $\mathrm{pg} / \mathrm{ml}$. The median IL-10 level is $2.96 \mathrm{pg} / \mathrm{ml}$ with a minimum level of $0 \mathrm{pg} / \mathrm{ml}$ and a maximum of 11 $\mathrm{pg} / \mathrm{ml}$. Table 1 shows the baseline characteristics of all samples.

From this study, a significant positive correlation was obtained between IL-17 and IL-10 levels in SLE patients with $p<0.001$ and $r=0.539$, as shown in Figure 1

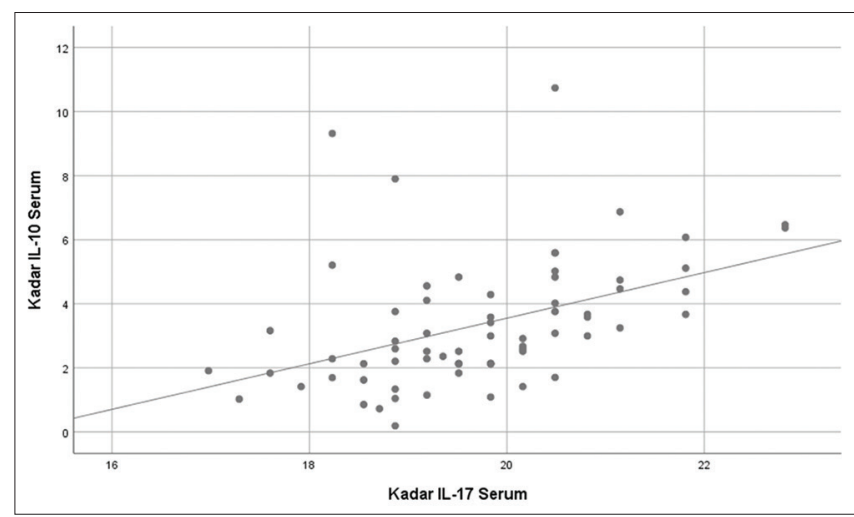

Figure 1: Correlation between interleukin-17 and interleukin-10 levels in systemic lupus erythematosus patients

This study shows that there is no significant mean difference between the IL-17 levels of the active and inactive SLE groups. IL-10 levels in active SLE were higher than inactive SLE but there were no significant differences between them (Table 2).

Table 2: Differences between IL-17 and IL-10 mean level with SLE disease activity

\begin{tabular}{llll}
\hline Variable & \multicolumn{2}{l}{ SLE } & $\mathrm{p}$ \\
\cline { 2 - 3 } & Active & Inactive & \\
\hline IL-17, mean (SD) & $19.67(1.299)$ & $19.78(1.187)$ & 0.711 \\
IL-10, median (min-max) & $3.63(1-11)$ & $2.52(0-6)$ & $0.099^{*}$ \\
\hline SLE: Systemic lupus erythematosus, IL: Interleukin, SD: Standard deviation & &
\end{tabular}

\section{Discussion}

In this study, there were 68 female subjects with SLE and no men with a median age of 31 years, and the most were between the ages of 21 and 40 years. Predomination of female sex is a characteristic of SLE disease as a systemic autoimmune disease, in which other studies showed the ratio of women/ men is 9/1-10-15/1, which can reach its peak at productive age as shown in this study. The influence of hormonal, cytokine, and genetic imbalances is thought to play a role in the predominance of female sex in this SLE. High estrogen levels and low progesterone 
in SLE affect the expression of toll-like receptor-17 mediated IFN- $\alpha$ and chemokine $\mathrm{C}-\mathrm{X}-\mathrm{C}$ ligand 10 in the peripheral so that it can cause disease progression and SLE disease activity through modulation of the IFN- $\alpha$ pathway [11], [12], [13].

The duration of SLE disease in this study obtained a median of 4.5 years with SLE disease $>1$ year more than $<1$ year ( $82.4 \%$ vs. $17.6 \%$ ). This is consistent with research conducted by Kakati et al. which showed that SLE disease duration $>1$ year $(71.7 \%)$ is more than $<1$ year $(28.3 \%)$. The Almenara Lupus cohort study showed a longer average LES disease of 7.7 years. Disease activity in this study was calculated based on the MEX-SLEDAI score obtained a median of 1 with a minimum value of 0 and a maximum of 17 . Based on the MEX-SLEDAI criteria, a score of $<2$ had mild activity, in this study categorized as an inactive SLE with a total of 34 subjects and scores $>2$ were categorized as active SLE with 34 subjects. In this study, the active SLE median obtained 8 with a minimum value of 2 and a maximum of 17 . The use of MEX-SLEDAI used in this study to determine disease activity because based on research by Freire et al., MEX-SLEDAI has a higher validity than other measuring devices such as British Island Lupus Assessment Group and Systemic Lupus Activity Measurement and do not require a fee for their use [14], [15], [16].

The mean IL-17 level in this study was 19.73 (1.24) $\mathrm{pg} / \mathrm{ml}$. It was seen that IL-17 levels in SLE patients were higher than those of Talaat et al., Yao et al., and Tsanakti et al. with the mean IL-17 levels were 17.7 (2.3) pg/ml, 18.23 (8.22) pg/ml, and 9.08 (1.39) pg/ml, respectively. Research by Galil et al. showed almost the same results as this study, which is $19.47(10.21) \mathrm{pg} / \mathrm{ml}$ and studies by Wong et al. and Vincent et al. showed a higher mean of IL-17, which are 76.5 (45.7) pg/ml and $140.6 \mathrm{pg} / \mathrm{ml}$ [17], [18], [19], [20], [21], [22].

This study also showed a correlation between IL-17 levels and IL-10 serum obtained a significant positive correlation with $p \leq 0.05$ and $r=0.539$. It can be seen that the pro-inflammatory activity of IL-17 is significantly proportional to the secretion of IL-10 from T-reg cells in SLE patients. This is consistent with the hypothesis showing that IL-17 and IL-10 have a positive correlation in SLE. IL-10 as an anti-inflammatory cytokine has the characteristics of cytokines as cytokines T-regulator cells especially $\mathrm{T}$ regulator type 1 cells (Tr1) which under normal circumstances can inhibit the response of $B$ cells which is an independent effect of IL-10. IL-10 itself is not only produced by T-reg cells but also produced by other T-helper cells that have regulatory functions, besides $\mathrm{IL}-10$ is also a cytokine that plays a role in the maturation and differentiation factors of B cells, so as to increase survival, proliferation, isotype changes, and $\mathrm{B}$ cell differentiation to plasma cells [23], [24].

In SLE, IL-10 has a proven pathogenic role in this study correlating with IL-17 levels which activate the formation of autoantibodies (autoreactive B cells) which have an impact on increasing disease activity and severity of SLE. A study by Facciotti et al. showed that mice with SLE secreted IL-10 by T-regulator cells and follicular T-helper (Tfh) cell populations which showed that in addition to T-regulator cell activity, autoreactive B cells also express pathogenic cytokines IL-10 spontaneously which induces the formation of autoantibodies in vitro, as well as the production of autoantibodies in mice in vivo, which until now the pathophysiological mechanism is still being investigated further, especially the role of follicular T-helper cells in the balance of Th17/Treg cells and Th1/Th2 cells. Analysis of IL-10 secretion in other $T$ cell subsets has also not been able to identify the unique cellular role of these cytokines. The paradoxical pathogenic activity of IL-10 in SLE is still interesting to study considering that the capacity of IL-10 has not yet been identified that independently stimulates the production of autoantibodies, so it is suspected that there is involvement of other T-set subset pathways that contribute to this stimulation. A study by Su et al. demonstrated the involvement of microRNA (miRNAs) in the stimulation of IL-10 in SLE. The dysregulation of miR-199-3p expression increases IL-10 production which targets Poly (ADP-ribose) polymerase-1 which is a serological marker found in SLE patients and is associated with inflammatory factors and cytokines, but the role of miRNA in the pathogenesis of SLE is still being evaluated, especially its impact on the clinical and activity of SLE disease [23], [24], [25], [26].

This study showed that there is no difference in the mean IL-17 serum levels of active and inactive SLE patients. This result is different from study conducted by Talaat et al. and Galil et al. which showed a significant mean difference between the IL-17 levels of active and inactive SLE patients, while the study of Zhao et al. which involved 41 active and 16 inactive SLE patients showed no significant mean difference between the two groups. The study conducted by Yao et al. showed that there was a mean difference between active and inactive SLE with $p=0.041$ although it was not related to disease activity score (SLEDAI). Yao et al. also classifying between active SLE with neuropsychiatric lupus involvement (NPSLE) and without NPSLE found no significant difference (18.23 and $18.77 \mathrm{pg} / \mathrm{ml})$. The comparison between IL-17 levels in active and inactive SLE patients still show different results in each study. Previous study has involved healthy controls as a comparison, in which it showed that active SLE patients secrete IL-17 influenced by the induction of adhesion molecules such as cell surface cadherin, integrin, selectins, ICAM-1, and VCAM, which when compared with controls healthy will show results of higher IL-17 levels, thus allowing the role of lymphocytes and antigen-presenting cells in the development of autoimmune responses, but studies in the inactive SLE group have not been conducted yet. In addition, defects in the development and activity of regulator T-CD4 cells both in terms of quantity and quality also affect the ability 
of cells to suppress the proliferation and production of IL-17 proinflammatory cytokines in immune cell effector in SLE patients, so there is a possibility that IL-17 can contribute to the ability of T-regulator cell inhibition due to reciprocal control in the formation and supervision of Th17 cells and T-regulator cells [17], [18], [19], [27].

The results of this study also showed no mean difference between IL-10 active and inactive SLE patients, but a median serum IL-10 value was higher in the active group than inactive. In addition, IL-10 levels also showed higher results than inactive SLE. Serum IL-10 was also found to be higher in the study of Koenig et al. that conducted in the SLE group with active nephritis compared to inactive and control SLE, although the sample used was limited to 12 subjects. A study by Godsell et al. involving 129 active SLE patients who underwent IL-10 examination at the first visit and continued 2 years later showed that serum IL-10 could be a predictive factor for the possibility of relapse in SLE patients. In the study, it was mentioned that patients with the highest quartile at the time of initial diagnosis of SLE had a 3.6-fold potential to experience active SLE in subsequent controls, and this result also correlated with SLE inflammatory markers such as erythrocyte sedimentation rate, anti-dsDNA, levels C3 and C4, and significant correlations were also obtained at the next SLE patient visit, so from this study it was seen that serum IL-10 levels might be a marker of disease activity in SLE patients [28], [29], [30].

\section{Conclusion}

There were no significant mean differences of IL-17 and IL-10 between active and inactive SLE patients on this study. However, we found elevated result of IL-10 in active SLE than inactive which described the activity of anti-inflammatory cytokines produced by T-regulatory cells were higher in active SLE. There was positive correlation between IL-17 and IL-10.

\section{References}

1. Carter E, Barr S, Clarke A. The global burden of SLE: Prevalence, health disparities and socioeconomic impact. Nat Rev Rheumatol. 2016;12(10):605-20. https://doi.org/10.1038/ nrrheum.2016.137 PMid:27558659

2. Stojan G, Petri M. Epidemiology of systemic lupus erythematosus: An update. Curr Opin Rheumatol. 2018;30(2):144-50. PMid:29251660

3. Rees F, Doherty M, Grainge MJ, Lanyon P, Zhang W. The worldwide incidence and prevalence of systemic lupus erythematosus: A systematic review of epidemiological studies. Rheumatology. 2017;56(11):1945-61. https://doi.org/10.1093/ rheumatology/kex260

PMid:28968809

4. Chavele K, Ehrenstein M. Regulatory T-cells in SLE and rheumatoid arthritis. FEBS. 2011;585(23):3603-10. https://doi. org/10.1016/j.febslet.2011.07.043

PMid:21827750

5. Sonawale A, Bohara $\mathrm{V}$, Bichile L. Evaluation of the association between CD4, CD8, CD25 cell counts and SLE in active disease and in remisson. J Assoc Physician India. 2017;65(4):37-42. PMid:28527162

6. Elvira D. The role of T-regulatory expression in autoimmune thyroid disease and its association with thyroid antibody. J Autoimmune Disord. 2016;2(2):19. https://doi.org/10.21767/2471-8513.100019

7. Stadhouders R, Lubberts E, Hendriks RW. Acellular and molecular view of T helper 17 cell plasticity in autoimmunity. J. Autoimmun. 2018;87:1-15. https://doi.org/10.1016/j.jaut.2017.12.007 PMid:29275836

8. Fasching P, Stradner M, Graninger W, Dejaco C, Fessler J. Therapeutic potential of targeting the Th17/Treg axis in autoimmune disorders. Molecules. 2017;22(1):134. https://doi. org/10.3390/molecules22010134 PMid:28098832

9. Rother N, Van der Vlag J. Disturbed T cell signaling and altered Th17 and regulatory $\mathrm{T}$ cell subsets in the pathogenesis of systemic lupus erythematosus. Front Immunol. 2015;6:610. https://doi.org/10.3389/fimmu.2015.00610 PMid:26648939

10. Guo B. IL-10 modulates Th17 pathogenicity during autoimmune diseases. J Clin Cell Immunol. 2016;7(2):400. https://doi. org/10.4172/2155-9899.1000400 PMid:27308096

11. Weckerie CE, Niewold TB. The unexplained female predominance of systemic lupus erythematosus: Clues from genetic and cytokine studies. Clin Rev Allergy Immunol. 2011;40(1):42-9. https://doi.org/10.1007/s12016-009-8192-4 PMid:20063186

12. Gergianaki I, Bertsias G. Systemic lupus erythematosus in primary care: An update and practical messages for the general practitioner. Front Med. 2018:5:161. https://doi.org/10.3389/ fmed.2018.00161

PMid:29896474

13. Zhang R, Li Y, Pan B, Li Y, Liu A, Li X. Increased expression of hub gene CXCL-10 in peripheral blood mononuclear cells of patients in systemic lupus erythematosus. Exp Ther Med. 2019;18(5):4067-75. https://doi.org/10.3892/etm.2019.8013 PMid:31616519

14. Kakati S, Teronpi R, Barman B. Frequency, pattern and determinants of flare in systemic lupus erythematosus. Egyp Rheumatol. 2015;37(4):S55-9. https://doi.org/10.1016/j. ejr.2015.08.002

15. Reategui-Sokolova C, Rodriguez-Bellido Z, GamboaCardenas RV, Medina M, Zevallos F, Pimentel-Quiroz VR, et al. Remission and low disease activity state prevent hospitalizations in systemic lupus erythematosus patients. Lupus. 2019;28(11):1344-9. https://doi.org/10.1177/0961203319876998 PMid:31551028

16. Freire EA, Souto LM, Ciconelli RM. Assessment measures in systemic lupus erythematosus. Rev Bras Reumatol. 2011;51(1):70-80.

PMid:21412607

17. Talaat RM, Mohamed SF, Bassyouni IH, Raouf AA. Th1/ 
Th2/Treg/Th17 cytokine imbalance in lupus erythematosus (SLE) patients: Correlation with disease activity. Cytokine. 2015;72(2):146-53. https://doi.org/10.1016/j.cyto.2014.12.027 PMid:25647269

18. Galil SM, Ezzeldin N, El-Boshy ME. The role of serum IL-17 and IL-6 as biomarkers of disease activity and predictors of remission in patients with lupus nephritis. Cytokine. 2015;76(2):280-7. https://doi.org/10.1016/j.cyto.2015.05.007 PMid:26073684

19. Yao Y, Wang JB, Xin MM, Li H, Liu B, Wang LL, et al. Balance between inflammatory and regulatory cytokines in systemic lupus erythematosus. Genet Mol Res. 2016;15(2):1-8. https:// doi.org/10.4238/gmr.15027626 PMid:27323066

20. Tsanaktsi A, Solomou EE, Liossis SN. Th1/17 cells, a subset of Th17 cells are expanded in patients with active systemic lupus erythematosus. Clin Immunol. 2018;195:101-6. https://doi. org/10.1016/j.clim.2018.08.005

21. Vincent FB, Northcott M, Morand EF. Clinical association of serum interleukin-17 in systemic lupus erythematosus. Arthritis Res Ther. 2013;15(4):R97. https://doi.org/10.1186/ar4277 PMid:23968496

22. Wong CK, Ho CY, Li EK, Lam CW. Elevation of proinflammatory cytokine (IL-18, IL-17, IL-12) and Th2 cytokine (IL-4) concentration in patients with systemic lupus erythematosus. Lupus. 2000;9(8):589-93. https://doi.org/10.1191/096120300678828703 PMid:11035433

23. Facciotti F, Larghi P, Bosotti R, Vasco C, Gagliani N, Cordiglieri C, et al. Evidence for a pathogenic role of extrafollicular, IL-10-producing CCR6+B helper T cells in systemic lupus erythematosus. PNAS. 2020;117(13):7305-16. https://doi. org/10.1073/pnas.1917834117

24. Wang T, Mei Y, Li Z. Research progress on regulatory B cells in systemic lupus erythematosus. BioMed Res Int. 2019;2019:1-7. https://doi.org/10.1155/2019/7948687

PMid:31240224

25. Geginat J, Vasco M, Gerosa M, Tas SW, Pagani M, Grassi F, et al. IL-10 producing regulatory and helper T-cells in systemic lupus erythematosus. Semin Immunol. 2019;44:101330. https:// doi.org/10.1016/j.smim.2019.101330

PMid:31735515

26. Su X, Ye L, Chen X, Zhang H, Zhou Y, Ding $X$, et al. MiR199-3p promotes ERK-mediated IL-10 production by targeting poly (ADP-ribose) polymerase- 1 in patients with systemic lupus erythematosus. Chem Biol Interact. 2019;306:110-6. https://doi. org/10.1016/j.cbi.2019.04.015 PMid:30991045

27. Zhao XF, Pan HF, Yuan H, Zhang WH, Li XP, Wang GH, et al. Increased serum interleukin 17 in patients with systemic lupus erythematosus. Mol Biol Rep. 2010;37(1):81-5. https://doi. org/10.1007/s11033-009-9533-3 PMid: 19347604

28. Godsell J, Rudloff I, Kandane-Rathnayake R, Hoi A, Nold MF, Morand EF, et al. Clinical associations of IL-10 and IL-37 in systemic lupus erythematosus. Sci Rep. 2016;6(34604):1-10. https://doi.org/10.1038/srep34604

29. Correa JE, Cortes MA, Uribe JA, Camacho LS. Comparison of plasma cytokine levels before and after treatment with rituximab in patients with rheumatoid arthritis and systemic lupus erythematosusassociated polyautoimmunity. Univ Med. 2018;59(3):21-36. https:// doi.org/10.11144/javeriana.umed59-3.cyto

30. Koenig KF, Groeschl I, Pesickova SS, Tesar V, Eisenberger U, Trendelenburg M. Serum cytokine profile in patients with active lupus nephritis. Cytokine. 2012;60(2):410-6. https://doi. org/10.1016/j.cyto.2012.07.004

PMid:22846145 